\title{
Fertilization of Two Container-grown Woody Ornamentals Based on Their Specific Nitrogen Accumulation Patterns
}

\author{
David R. Sandrock, ${ }^{1}$ Anita N. Azarenko, and Timothy L. Righetti \\ Department of Horticulture, Oregon State University, 4017 Ag and Life Sciences \\ Building, Corvallis, OR 97331
}

Additional index words. container-grown, nursery, nitrogen uptake, sliding scale, Weigela florida 'Red Prince', Euonymus alatus 'Compactus'

\begin{abstract}
Nitrogen accumulation patterns were established for Weigela florida (Bunge.) A. DC. 'Red Prince' (fast growth rate) and Euonymus alatus (Thunb.) Sieb. 'Compactus' (slow growth rate). From these, daily and biweekly $\mathrm{N}$ delivery schedules were designed to match $\mathbf{N}$ supply with $\mathbf{N}$ accumulation patterns of each taxon. Delivery schedules were sliding scales in that total $\mathrm{N}$ applied was controlled by independent increases (or decreases) of $\mathbf{N}$ concentration and solution volume. Daily and biweekly $\mathbf{N}$ delivery schedules were tested against a constant $N$ rate $\left(200 \mathrm{mg} \cdot \mathrm{L}^{-1}\right)$ and Osmocote $18 \mathrm{~N}-2.6 \mathrm{P}-9.9 \mathrm{~K}$ (The Scotts Co., Marysville, Ohio). Plants were grown in 3.8-L containers in 7 douglas fir bark : 2 sphagnum peatmoss : 1 silica sand $(0.65 \mathrm{~mm}$; by volume) outdoors in full sun on aravel pad for $142 \mathrm{~d}$. Within each taxon, Weigela and Euonymus grown with sliding-scale N fertilization schedules had similar total dry weights, leaf areas, and total plant $\mathrm{N}$ contents to plants grown with a constant $N$ rate $\left(200 \mathrm{mg} \cdot \mathrm{L}^{-1}\right)$ or Osmocote $18 \mathrm{~N}-2.6 \mathrm{P}-9.9 \mathrm{~K}$. Sliding-scale liquid fertilization based on plant $\mathrm{N}$ requirements introduced less total $\mathrm{N}$ to the production cycle and resulted in higher $\mathrm{N}$ uptake efficiency than fertilization with a constant $N$ rate of $200 \mathrm{mg} \cdot \mathrm{L}^{-1}$. In general, liquid $N$ fertilizer treatments resulted in plants with higher shoot to root ratios than plants treated with Osmocote $18 \mathrm{~N}-2.6 \mathrm{P}-9.9 \mathrm{~K}$. Weigela and Euonymus treated with biweekly schedules were similar to plants treated with daily schedules (same total amount of $\mathbf{N}$ delivered with each treatment).
\end{abstract}

Nitrogen $(\mathrm{N})$ is commonly applied to container nursery crops as controlled-release fertilizer(CRF) or soluble $\mathrm{N}$ delivered through irrigation. A recent survey in the southeastern United States reported that $100 \%$ of nurseries polled applied CRFs as their primary source of plant nutrients while $75 \%, 25 \%$, and $25 \%$ of small, medium, and large nurseries, respectively, used liquid fertilization to meet the nutrient requirements of their liners (Fain et al., 2000). In theory, single or infrequent applications of a CRF can meet the nutrient requirements of plants thereby requiring less labor to apply and manage than other fertilization methods (Yeager and Cashion, 1993). In addition, CRFs may reduce $\mathrm{N}$ leaching and buildup of soluble salts (Bunt, 1988; Maynard and Lorenz, 1980). Soluble nutrients are delivered through irrigation to fertilize small liner material (Fain et al., 2000), high value greenhouse crops (Cabrera et al., 1993) and containers with depleted CRFs. Similar growth and quality of container-grown plants can be achieved with CRFs or soluble $\mathrm{N}$ fertilizers (Hershey and Paul, 1982; Johnson et al., 1981; Wright and Niemiera, 1987), yet both exhibit inherent inefficiencies.

Nitrogen fertilization with CRFs may be

Received for publication 4 June 2004. Accepted for publication 19 Aug. 2004

${ }^{1}$ Reprint requests should be addressed to David Sandrock, Department of Environmental Horticulture, University of Florida, P.O. Box 110675, Gainesville, Florida 32611; e-mail dsandrock@ifas.ufl.edu. inefficient because $\mathrm{N}$ release patterns often do not match the N requirements of plants and can vary with environmental conditions (Cabrera, 1997; Huett, 1997; Meadows and Fuller, 1983; Wright and Niemiera, 1987). High N release rates may occur early in the growing season when plants are small, $\mathrm{N}$ requirements are relatively low, and limited root systems are unable to take up available $\mathrm{N}$ (Wright and Niemiera, 1987). Later in the season, depleted CRFs may not release enough $\mathrm{N}$ for large, actively growing plants with fully developed root systems and relatively high $\mathrm{N}$ requirements. Furthermore, a CRF applied at a generalized rate will not match the $\mathrm{N}$ requirements of the various species and cultivars commonly grown at commercial container nurseries (Hinklenton and Cairns, 1992; Whitcomb, 1986). A single application rate may provide excess $\mathrm{N}$ to dwarf, slow growing, or low $\mathrm{N}$ requiring taxa while simultaneously failing to meet the $\mathrm{N}$ requirements of large, vigorous, or high $\mathrm{N}$ requiring taxa.

Delivery of soluble N through overhead irrigation is inefficient because much of the water applied and dissolved $\mathrm{N}$ never reaches the plant roots, falling instead between containers or in roadways (Beeson and Knox, 1991; Yeager et al., 1986). When overhead irrigation was used to fertilize 0.405 ha of $3.8 \mathrm{~L}$ containers $(10,839$ plants), $81 \%$ of the fertilizer fell outside of containers (Yeager et al., 1986). Plants at close and $7.6 \mathrm{~cm}$ spacing resulted in $37 \%$ and $25 \%$ irrigation application efficiencies, respectively
(Beeson and Knox, 1991). Container spacing, shedding of water by the plant canopy, and evaporation of water retained on the plant canopy are the main factors associated with low efficiencies in overhead irrigation systems (Beeson and Knox, 1991).

Regardless of form, applying excess $\mathrm{N}$ to container production systems promotes $\mathrm{N}$ leaching (Cabrera et al., 1993; Hershey and Paul, 1982; van der Boon and Niers, 1983, Yeager et al., 1993) and may depress plant growth (Barnett and Ormrod, 1985; Cabrera, 2003; Cabrera and Devereaux, 1998). In contrast, supplying insufficient $\mathrm{N}$ reduces plant size and quality (Marschner, 1995; Mengel and Kirkby, 1987). Therefore, designing fertilization strategies to maximize plant growth and quality while minimizing $\mathrm{N}$ input is essential to maintaining nursery profits and reducing $\mathrm{N}$ leaching.

Several studies have observed plant growth and plant $\mathrm{N}$ status across a range of $\mathrm{N}$ concentrations in the potting substrate (Barnett and Ormrod, 1985; Cabrera, 2003; Cabrera and Devereaux, 1998; Dubois et al., 2000; Griffin et al., 1999; Henry et al., 1992; Jull et al., 1994; Niemiera and Wright, 1982). These studies often result in recommendations of constant $\mathrm{N}$ concentrations in the substrate for optimum growth of specific plant taxa. However, these recommendations do not take into account that plants may take up $\mathrm{N}$ at different rates during the growing season. Furthermore, plant growth is not a direct response to $\mathrm{N}$ concentration but to total nutrient availability (Wright and Niemiera, 1987). While plants are actively growing, $\mathrm{N}$ absorption increases with increasing dry weight gain. Therefore, $\mathrm{N}$ supply must be simultaneously increased (Ingestad, 1982).

Sliding-scale fertilization matches N supply to plant $\mathrm{N}$ requirements and is based on plant $\mathrm{N}$ accumulation patterns and plant $\mathrm{N}$ uptake efficiency over time. It allows for the uncoupled increase (or decrease) of $\mathrm{N}$ concentration and irrigation volume, making it possible to match $\mathrm{N}$ and water supply to changing $\mathrm{N}$ and water requirements of a growing plant. During implementation of a sliding-scale fertilization schedule, total $\mathrm{N}$ supply (amount) can be increased by applying the same concentration at increasing volumes, applying the same concentration more frequently, or by increasing the $\mathrm{N}$ concentration of the solution applied (Ingestad, 1982).

To design a sliding-scale fertilization schedule for a plant taxon, its seasonal $\mathrm{N}$ accumulation pattern must first be defined. The $\mathrm{N}$ accumulation patterns for several woody species have been determined (Craig et al., 2003; Hanson and Howell, 1995; Hilen and Good, 1985; Munoz et al., 1993; Rose and Biernacka, 1999; Wienbaum et al., 1978), but few attempts have been made to develop or test $\mathrm{N}$ delivery programs based directly on $\mathrm{N}$ accumulation patterns. For an herbaceous crop, poinsettias (Euphorbia pulcherrima Willd. ex. Klotzch), sliding-scale $\mathrm{N}$ fertilization based on established $\mathrm{N}$ accumulation patterns was developed and tested (Rose et al., 1994). At initiation, plants were fertilized with $\mathrm{N}$ at a rate of $75 \mathrm{mg} \cdot \mathrm{L}^{-1}$. 
Nitrogen rate was increased by $25 \mathrm{mg} \cdot \mathrm{L}^{-1}$ about every $14 \mathrm{~d}$, reaching a maximum of $150 \mathrm{mg} \cdot \mathrm{L}^{-1}$, and was then decreased to a final $\mathrm{N}$ concentration of $100 \mathrm{mg} \cdot \mathrm{L}^{-1}$. Poinsettias fertilized with the sliding-scale $\mathrm{N}$ fertilization regime exhibited higher $\mathrm{N}$ recovery efficiency $(58 \%)$ than those fertilized at a constant $\mathrm{N}$ rate of $200 \mathrm{mg} \cdot \mathrm{L}^{-1}$ (38\%). Furthermore, the sliding-scale treatment introduced $41 \%$ less $\mathrm{N}$ to the production system than the constant rate treatment.

We propose that sliding-scale $\mathrm{N}$ fertilization programs can be developed for container-grown woody plants based on their $\mathrm{N}$ accumulation patterns. Furthermore, plants comparable to those grown with constant rate liquid fertilization or CRFs can be produced. The first objective of this work was to determine the dry matter increase and $\mathrm{N}$ accumulation patterns for Weigela florida 'Red Prince', (fast growth rate) and Euonymus alatus 'Compactus', (slow growth rate). The second objective was to design sliding-scale liquid $\mathrm{N}$ fertilization schedules specific to Weigela and Euonymus based on their established $\mathrm{N}$ accumulation patterns. The third objective was to compare plants grown under the sliding-scale liquid $\mathrm{N}$ fertilization program to plants fertilized with constant rate liquid fertilization or a CRF.

\section{Materials and Methods}

The purpose of the 2001 trial was to determine the optimal $\mathrm{N}$ concentration, dry weight increase and $\mathrm{N}$ accumulation patterns for Weigela and Euonymus. On 1 Apr. 2001, uniform rooted stem cuttings of Euonymus and Weigela were potted into 3.8-L containers filled with 7 fresh douglas fir [Pseudotsuga menziesii (Mirb.) Franco.] bark (initial pH of 3.6) : 2 sphagnum peatmoss : 1 silica sand $(0.65 \mathrm{~mm})$ by volume. The substrate was amended with $0.883 \mathrm{~kg}$ Micromax (The Scotts Co., Marysville, Ohio), $1.77 \mathrm{~kg}$ calcitic lime $\left(\mathrm{CaCO}_{3}\right), 1.77$ $\mathrm{kg}$ dolomitic lime $\left(\mathrm{CaCO}_{3}+\mathrm{MgCO}_{3}\right), 1.05 \mathrm{~kg}$ 8 to 9 month slow release phosphorous (2.6P; The Scotts Co.), and $1.18 \mathrm{~kg} 8$ to 9 month slow release potassium $(9.9 \mathrm{~K}$; The Scotts Co.) all per $\mathrm{m}^{3}$. Substrate $\mathrm{pH}$ at transplanting (after all amendments were added) was 5.6. Trials were conducted in full sun at the Lewis Brown Horticulture Farm in Corvallis, Ore (latitude: 44.5 north, longitude: 123.2 west).

Optimal N concentration (2001). To con- firm the optimal $\mathrm{N}$ concentration for growth of Weigela and Euonymus, 50 plants of each taxon were arranged in a completely randomized design and supplied with $\mathrm{N}$ concentrations of $25,50,100,200$, or $300 \mathrm{mg} \cdot \mathrm{L}^{-1}$. Nitrogen was supplied as ammonium nitrate $\left(\mathrm{NH}_{4} \mathrm{NO}_{3}\right.$; Western Farm Services, Tangent, Ore.) on alternate days beginning on 1. Apr. Applied solution volume was $150 \mathrm{~mL} /$ container at initiation and was increased to maintain a $25 \%$ leaching fraction, as monitored every two weeks, reaching a final volume of 300 $\mathrm{mL} /$ container. After 16 June, supplemental irrigation was delivered on alternate days when plants did not receive $\mathrm{N}$ applications. On 7 July, five randomly selected plants from each taxon and each $\mathrm{N}$ concentration were partitioned into leaves, roots, and shoots. Leaf area was determined with the LI-COR 3100 Leaf Area Meter (Lincoln, Neb.). All tissues were dried at $65^{\circ} \mathrm{C}$ for at least $96 \mathrm{~h}$, weighed, ground (Wiley Mini-mill; Thomas Scientific, Swedeboro, N.J.) to pass a $0.85-\mathrm{mm}$ sieve, and analyzed for total $\mathrm{N}$ by the Kjeldahl procedure (Horneck et al., 1989).

Dry weight and $N$ accumulation patterns (2001). To determine the dry weight gain and $\mathrm{N}$ accumulation pattern of Weigela and Euonymus, 60 plants of each taxon were arranged in a completely randomized design and supplied $\mathrm{N}$ as ammonium nitrate $\left(\mathrm{NH}_{4} \mathrm{NO}_{3}\right.$; Western Farm Services) at a concentration of $200 \mathrm{mg} \cdot \mathrm{L}^{-1}$. Solutions were applied on alternate days beginning on 9. Apr. Solution volume and irrigation were the same as applied for the previously described experiment. Plants were harvested on 14 May, 11 June, 9 July, and 6 Aug. At each harvest, four randomly selected plants of each taxon were partitioned into leaves, roots, and shoots. All tissues were dried at $65{ }^{\circ} \mathrm{C}$ for at least $96 \mathrm{~h}$, weighed, ground (Wiley Mini-mill; Thomas Scientific, Swedeboro, N.J.) to pass a $0.85-\mathrm{mm}$ sieve, and analyzed for total $\mathrm{N}$ by the Kjeldahl procedure (Horneck et al., 1989).

Calculation of a sliding-scale liquid fertilization regime. Sliding-scale fertilizer $\mathrm{N}$ treatments applied in 2002 were designed from total plant $\mathrm{N}$, periodic $\mathrm{N}$ uptake, and percent $\mathrm{N}$ uptake values from plants grown at an $\mathrm{N}$ concentration of $200 \mathrm{mg} \cdot \mathrm{L}^{-1}$ during 2001. Five sequential $N$ delivery periods were designed for 2002: $35,14,28,28$, and $35 \mathrm{~d}$ periods, respectively. Nitrogen requirements for Weigela and Euonymus were estimated with regression equations established in year 1. Nitrogen required by each taxon for each period was determined by subtracting total plant $\mathrm{N}$ of previous periods from total plant $\mathrm{N}$ of the period being calculated. The amount of $\mathrm{N}$ applied for each period was calculated by dividing the amount of $\mathrm{N}$ required per period by the percent $\mathrm{N}$ uptake during that period.

Comparison of plants grown with a slidingscale $N$ fertilization schedule, constant $N$ rate, and a CRF (2002). On 1 Apr. 2002, uniform rooted cuttings of Weigela and Euonymus were transplanted into 3.8-L containers. Forty plants of each taxon were arranged in a completely randomized design in full sun on a gravel pad at Oregon State University's Lewis Brown Horticulture Farm (Corvallis, Ore.).

Treatments included 8 to 9 month release Osmocote 18N-2.6P-9.9K (The Scotts Co.) incorporated or top dressed at the manufacturer's recommended high and medium rate (INC-HI, TOP-HI, TOP-HI(30), INC-MED, and TOP-MED), one constant $\mathrm{N}$ rate treatment (CONST), and two sliding-scale $\mathrm{N}$ treatments (WG-DLY and WG-BIWK for Weigela; EU-DLY and EU-BIWK for Euonymus; Table 1). Osmocote treatments and the constant $\mathrm{N}$ rate liquid treatment were applied to both taxa. Sliding-scale treatments were applied only to the taxon for which they were designed. A detailed description of the sliding-scale treatments is provided (Table 2).

Substrate and amendments for plants receiving sliding-scale and constant rate liquid $\mathrm{N}$ treatments were the same as for the previous year (2001). The substrate for plants receiving Osmocote treatments was amended with 0.883 kg Micromax (The Scotts Co.), $1.77 \mathrm{~kg}$ calcitic lime $\left(\mathrm{CaCO}_{3}\right), 1.77 \mathrm{~kg}$ dolomitic lime $\left(\mathrm{CaCO}_{3}\right.$ $+\mathrm{MgCO}_{3}$ ) all per cubic meter. The $\mathrm{pH}$ of both substrates, after all amendments were added, was 5.8 to 6.0 .

Plants were harvested on 20 Aug. Potting substrate was washed from the roots and plants were partitioned into leaves, roots, and shoots. All tissues were dried, weighed, ground (Wiley Mini-mill; Thomas Scientific, Swedeboro, N.J.) to pass a $0.85 \mathrm{~mm}$ sieve, and analyzed for total $\mathrm{N}$ by the Kjeldahl procedure (Horneck et al., 1989).

Leachate was collected on 3 May and 2 July using the pour-through extraction method

Table 1. Summary of treatments applied to Weigela florida 'Red Prince' and Euonymus alatus 'Compactus' grown in 3.8-L containers for 140 d (1 Apr.-18 Aug.) during 2002.

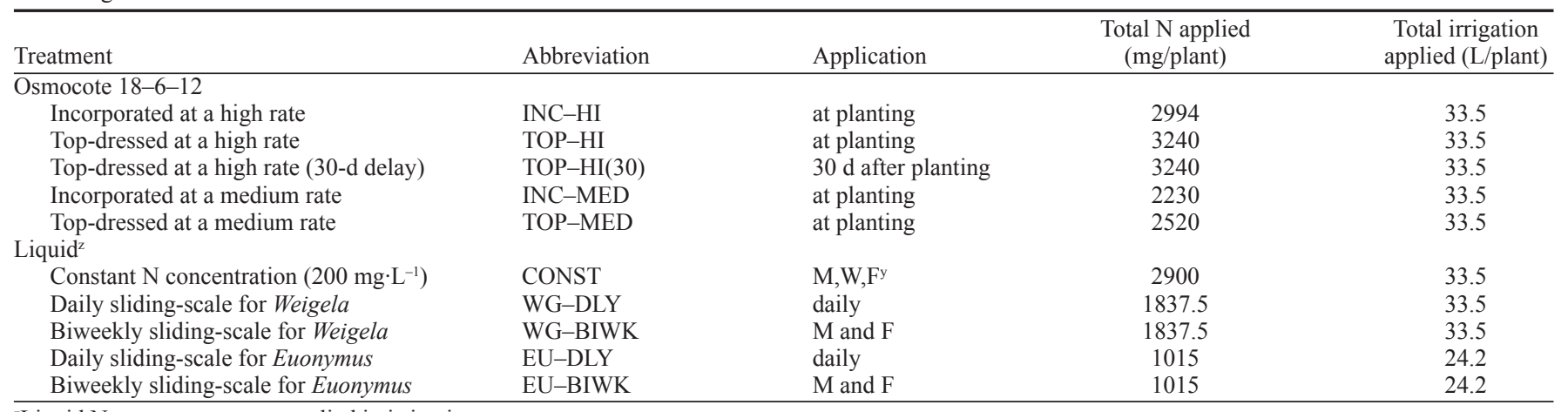

${ }^{2}$ Liquid $\mathrm{N}$ treatments were supplied in irrigation water.

${ }^{\mathrm{y}} \mathrm{M}=$ Monday, $\mathrm{W}=$ Wednesday, $\mathrm{F}=$ Friday. 
Table 2. Sliding-scale liquid N treatments applied to Weigela florida 'Red Prince' and Euonymus alatus 'Compactus' grown in 3.8-L containers for 140 d during 2002.

\begin{tabular}{|c|c|c|c|c|c|c|}
\hline \multirow[b]{2}{*}{ Treatment } & \multicolumn{5}{|c|}{ Period } & \multirow[b]{2}{*}{ Total } \\
\hline & $\begin{array}{l}\text { Apr.-- } \\
5 \text { May }\end{array}$ & $\begin{array}{l}6 \text { May- } \\
19 \text { May }\end{array}$ & $\begin{array}{l}20 \text { May- } \\
16 \text { June }\end{array}$ & $\begin{array}{l}17 \text { June- } \\
14 \text { July }\end{array}$ & $\begin{array}{l}15 \text { July- } \\
18 \text { Aug. }\end{array}$ & \\
\hline \multicolumn{7}{|l|}{ WG-DLY (delivered daily) } \\
\hline \multicolumn{7}{|l|}{ WG-BIWK (delivered twice a week) } \\
\hline$[\mathrm{N}]\left(\mathrm{mg} \cdot \mathrm{L}^{-1}\right)$ & 0 & 50 & 262.5 & 262.5 & 196.8 & --- \\
\hline Number of $\mathrm{N}$ applications & 0 & 4 & 8 & 8 & 10 & 30 \\
\hline Total irrigation $(\mathrm{L})$ & 5.25 & 2.1 & 5.4 & 6.75 & 14.0 & 33.5 \\
\hline Total N (mg) & 0 & 105 & 420 & 525 & 787.5 & 1837.5 \\
\hline \multicolumn{7}{|l|}{ EU-DLY (delivered daily) } \\
\hline$[\mathrm{N}]\left(\mathrm{mg} \cdot \mathrm{L}^{-1}\right)$ & 0 & 0 & 50 & 50 & 75 & --- \\
\hline Number of $\mathrm{N}$ applications & 0 & 0 & 28 & 28 & 34 & 90 \\
\hline \multicolumn{7}{|l|}{ EU-BIWK (delivered twice a week) } \\
\hline$[\mathrm{N}]\left(\mathrm{mg} \cdot \mathrm{L}^{-1}\right)$ applied $\mathrm{M}$ and $\mathrm{F}$ & 0 & 0 & 175 & 175 & 262.5 & --- \\
\hline
\end{tabular}

(Wright, 1984), and $\mathrm{pH}$ and electrical conductivity (EC) were determined with a $\mathrm{pH}$-conductivity meter(AccumetAR20; Fisher Scientific). Air temperature and rainfall data were collected with a weather station (WS-100; Rain Bird International Inc., Glendora, Calif.).

Because sliding-scale $\mathrm{N}$ treatments were applied specifically to the taxon they were designed for, only comparisons within a taxon were analyzed. No comparisons were made across taxa. Regression analysis, analysis of variance (ANOVA), mean separations, and orthogonal contrasts were performed using SAS v. 8.02 (SAS Institute, Cary, N.C.).

\section{Results and Discussion}

Optimal $N$ concentration (2001). Leaf area, total plant dry weight, and total plant $\mathrm{N}$ content were similar for both taxa at an $\mathrm{N}$ concentration of $25 \mathrm{mg} \cdot \mathrm{L}^{-1}$ (Fig. $1 \mathrm{~A}-\mathrm{C}$ ). As N concentration increased from 25 to $200 \mathrm{mg} \cdot \mathrm{L}^{-1}$, leaf area, total plant dry weight, and total plant $\mathrm{N}$ content of Weigela and Euonymus exhibited quadratic saturation response curves, but $\mathrm{Wei}$ gela reached higher values than Euonymus. For both taxa, leaf area, total plant dry weight, and total plant $\mathrm{N}$ content declined slightly at an $\mathrm{N}$ concentration of $300 \mathrm{mg} \cdot \mathrm{L}^{-1}$. Leaf area of Weigela and Euonymus reached maximum values of 2373 and $189 \mathrm{~cm}^{2}$, respectively, at an $\mathrm{N}$ concentration of $200 \mathrm{mg} \cdot \mathrm{L}^{-1}$. Maximum total plant dry weight values occurred at an $\mathrm{N}$ concentration of $200 \mathrm{mg} \cdot \mathrm{L}^{-1}$ for both taxa, 31.5 and $5.8 \mathrm{~g}$ for Weigela and Euonymus, respectively. Similarly, maximum total plant $\mathrm{N}$ values occurred for both taxa at an $\mathrm{N}$ concentration of $200 \mathrm{mg} \cdot \mathrm{L}^{-1}, 523$ and $130 \mathrm{mg}$ for Weigela and Euonymus, respectively. These data indicate that an $\mathrm{N}$ concentration of 200 $\mathrm{mg} \cdot \mathrm{L}^{-1}$ is optimum for growth of Weigela and Euonymus. For other container-grown taxa, optimum $\mathrm{N}$ concentration values between 50 and $150 \mathrm{mg} \cdot \mathrm{L}^{-1}$ have been reported (Barnett and Ormrod, 1985; Cabrera, 2003; Cabrera and Devereaux, 1998; Griffin et al., 1999; Niemiera and Wright, 1982). Some studies have reported negative effects on growth at $\mathrm{N}$ concentrations beyond 50 or $60 \mathrm{mg} \cdot \mathrm{L}^{-1}$ (Barnett and Ormrod, 1985; Cabrera, 2003; Cabrera and Devereaux, 1998), and the growth reduction has been attributed to high growing substrate salinity

(Cabrera and Devereaux, 1998). In this study, negative effects on growth were not observed across $\mathrm{N}$ concentrations of 25 to $300 \mathrm{mg} \cdot \mathrm{L}^{-1}$, possibly because the experimental period of $98 \mathrm{~d}$ did not provide enough time for salinity to build to detrimental levels.

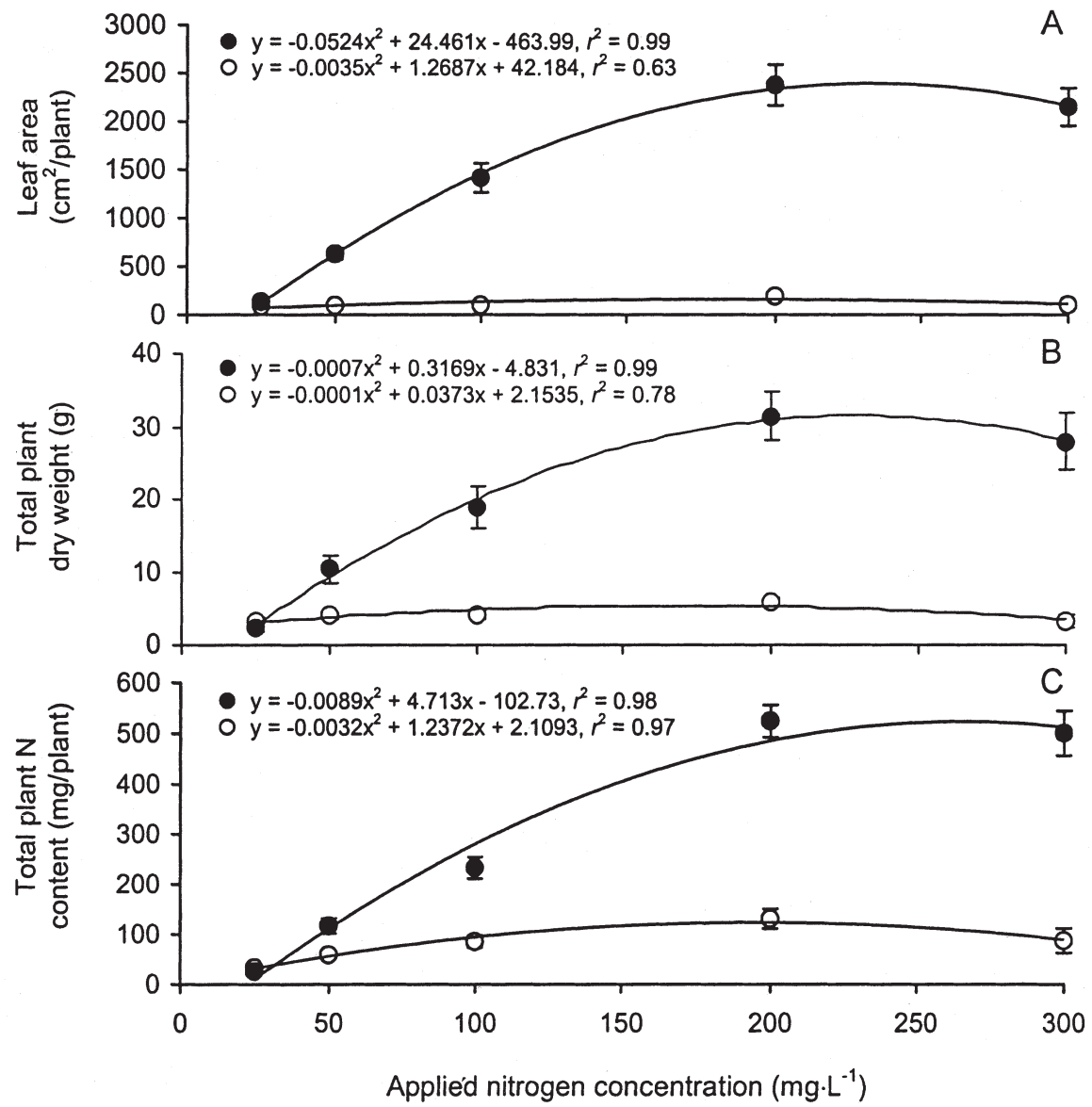

Fig 1. Leaf area (A), total plant dry weight (B), and total plant $\mathrm{N}$ content (C) of Weigela florida 'Red Prince' $(-$ and Euonymus alatus 'Compactus' $(\bigcirc)$. Plants were grown from rooted cuttings in $3.8 \mathrm{~L}$ containers for $98 \mathrm{~d}$ (1 Apr.-7 July, 2001) and supplied $\mathrm{N}$ at concentrations of 25, 50, 100, 200, and 300 $\mathrm{mg} \cdot \mathrm{L}^{-1}$ on alternating days. Error bars indicate \pm SE. 
scale liquid programs that better match plant
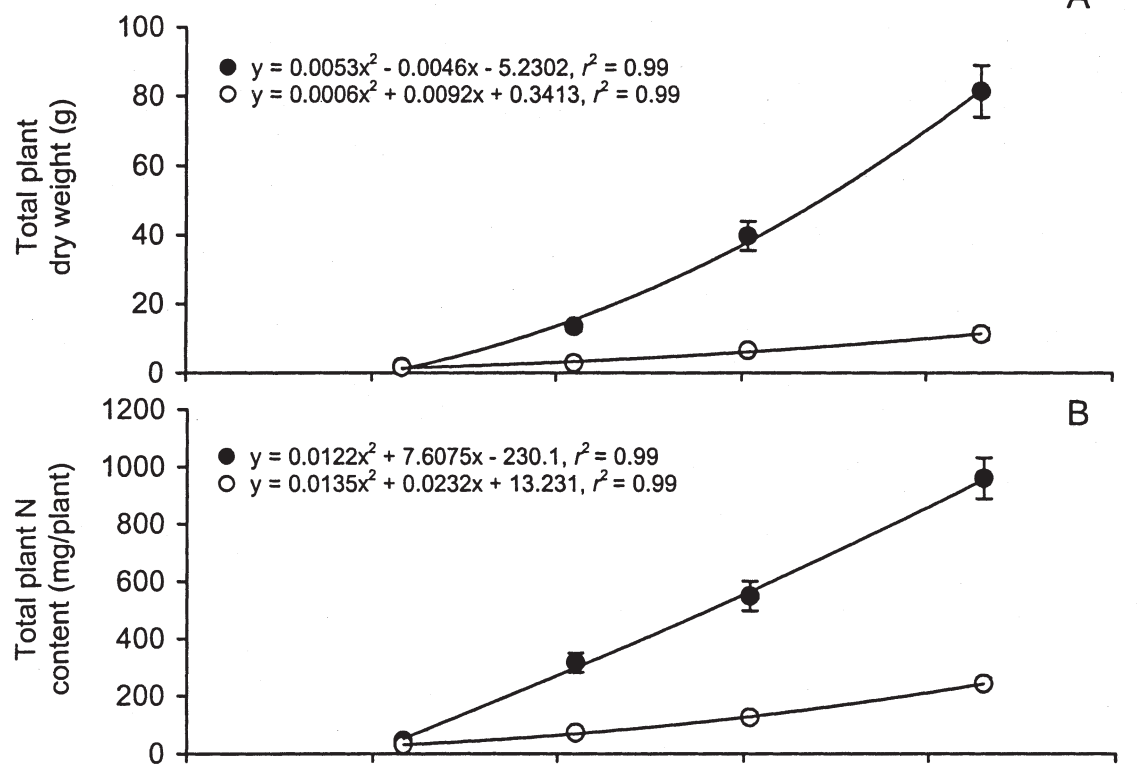

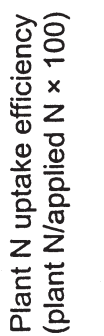

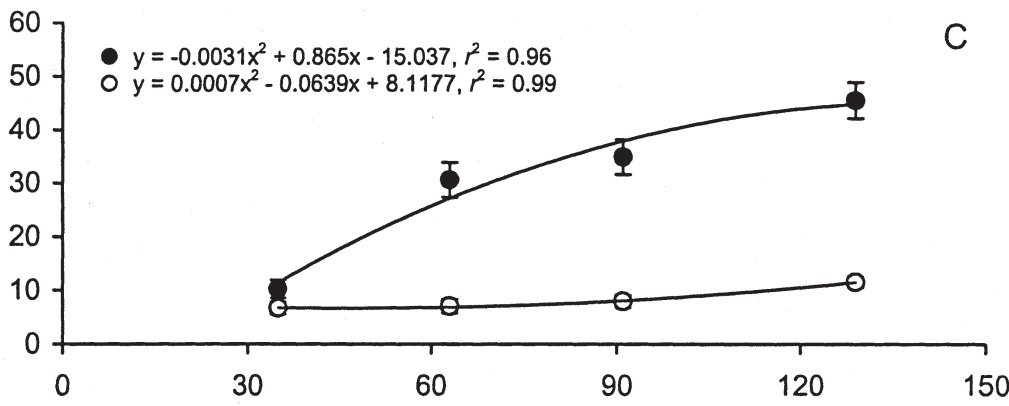

Time (days after $\mathrm{N}$ application began)

Fig 2. Total plant dry weight (A), total plant $\mathrm{N}$ content $(\mathbf{B})$, and plant $\mathrm{N}$ uptake efficiency (plant $\mathrm{N} /$ applied $\mathrm{N} \times 100)(\mathbf{C})$ for Weigela florida 'Red Prince' $(\mathbf{O})$ and Euonymus alatus 'Compactus' $(\mathrm{O})$. Plants were grown from rooted cuttings in 3.8-L containers for $128 \mathrm{~d}$ (1 Apr.-6 Aug., 2001) and supplied $\mathrm{N}$ at a concentration of $200 \mathrm{mg} \cdot \mathrm{L}^{-1}$ on alternating days. Error bars indicate $\pm \mathrm{SE}$.

Dry weight increase and $N$ accumulation (2001). At an $\mathrm{N}$ concentration of $200 \mathrm{mg} \cdot \mathrm{L}^{-1}$, total plant dry weight, total plant $\mathrm{N}$ content, and plant $\mathrm{N}$ uptake efficiency differed dramatically over time for Weigela and Euonymus (Fig. 2 A-C). At the first harvest (35 d after $\mathrm{N}$ applications began), total plant dry weight, total plant $\mathrm{N}$ content, and plant $\mathrm{N}$ uptake efficiency were similar and relatively low for both taxa. Thereafter, each attribute was higher for Weigela than Euonymus. Total plant dry weight accumulation for both taxa was best defined by quadratic equations. Dry weight accumulation patterns for container-grown Thuja occidentalis L. 'Smaragd', Cotoneaster dammeri C.K. Schneid. 'Coral Beauty', and Aronia arbutifolia (L.) Pers. 'Brilliantissima' were also best defined by quadratic equations (Craig et al., 2003). Total plant $\mathrm{N}$ of Weigela and Euonymus increased from 44.9 and 29.4 $\mathrm{mg} /$ plant, respectively, at $35 \mathrm{~d}$ after treatments began to 958.5 and $242.2 \mathrm{mg} /$ plant, respectively, at $120 \mathrm{~d}$ after treatments began. These results agree with other studies that indicated plant $\mathrm{N}$ requirements change with dry matter accumulation and growth stage (Argo and Biernbaum, 1991; Craig et al., 2003; Hanson and Howell, 1995; Hilen and Good,
1985; King and Stimart, 1990; Munoz et al., 1993; Rose and Biernacka, 1999; Wienbaum et al., 1978). When both taxa are grown at an $\mathrm{N}$ concentration of $200 \mathrm{mg} \cdot \mathrm{L}^{-1}$, Weigela exhibits greater dry weight gain, $\mathrm{N}$ uptake, and $\mathrm{N}$ uptake efficiency than Euonymus. Knowledge of plant $\mathrm{N}$ accumulation patterns will allow for the design of CRF or sliding-

Table 3. Total dry weight, leaf area, total plant $\mathrm{N}$ content, and shoot:root ratio of Weigela florida 'Red Prince' grown in 3.8-L containers with controlled-release, constant $\mathrm{N}$ rate, and sliding-scale liquid $\mathrm{N}$ fertilizer treatments (2002).

\begin{tabular}{lcccc}
\hline Treatment & $\begin{array}{c}\text { Total dry } \\
\mathrm{wt}(\mathrm{g})\end{array}$ & $\begin{array}{c}\text { Leaf area } \\
\left(\mathrm{cm}^{2}\right)\end{array}$ & $\begin{array}{c}\text { Total plant } \mathrm{N} \\
(\mathrm{mg})\end{array}$ & $\begin{array}{c}\text { Shoot to } \\
\text { root ratio }\end{array}$ \\
\hline INC-HI & $58.7 \mathrm{a}^{\mathrm{y}}$ & $2967.4 \mathrm{a}$ & $914.4 \mathrm{a}$ & $6.2 \mathrm{~b}$ \\
TOP-HI & $51.5 \mathrm{a}$ & $2463.5 \mathrm{c}$ & $554.2 \mathrm{~cd}$ & $4.7 \mathrm{~b}$ \\
TOP-HI(30) & $55.0 \mathrm{a}$ & $2656.0 \mathrm{abc}$ & $503.5 \mathrm{~d}$ & $4.8 \mathrm{~b}$ \\
INC-MED & $54.2 \mathrm{a}$ & $2533.0 \mathrm{bc}$ & $672.8 \mathrm{bc}$ & $4.9 \mathrm{~b}$ \\
TOP-MED & $52.3 \mathrm{a}$ & $2560.0 \mathrm{bc}$ & $597.4 \mathrm{~cd}$ & $5.2 \mathrm{~b}$ \\
CONST & $51.3 \mathrm{a}$ & $2818.6 \mathrm{ab}$ & $913.7 \mathrm{a}$ & $8.3 \mathrm{a}$ \\
WG-DLY & $51.9 \mathrm{a}$ & $2854.6 \mathrm{ab}$ & $784.4 \mathrm{ab}$ & $6.4 \mathrm{~b}$ \\
WG-BIWK & $53.4 \mathrm{a}$ & $2664.1 \mathrm{abc}$ & $803.1 \mathrm{ab}$ & $5.8 \mathrm{~b}$ \\
\hline
\end{tabular}

${ }^{2} \mathrm{INC}-\mathrm{HI}=$ incorporate at the high rate $\left(7.12 \mathrm{~kg} \cdot \mathrm{m}^{-3}\right), \mathrm{TOP}-\mathrm{HI}=$ top-dress at the high rate $(18 \mathrm{~g} /$ container $)$, TOP-HI $(30)=$ top-dress at the high rate $30 \mathrm{~d}$ after planting, INC-MED $=$ incorporate at the medium rate $\left(5.34 \mathrm{~kg} \cdot \mathrm{m}^{-3}\right)$, TOP-MED $=$ topdress at the medium rate $(14 \mathrm{~g} /$ container $), \mathrm{CONST}=200 \mathrm{mg} \cdot \mathrm{L}^{-1} \mathrm{~N}$ delivered Monday, Wednesday, and Friday, WG-DLY = daily sliding-scale treatments to Weigela florida 'Red Prince', WG-BIWK = biweekly sliding-scale treatments to Weigela florida 'Red Prince'.

'Means within columns followed by the same letter are not significantly different $(\alpha=0.05)$ by Duncan's multiple range test. 
Table 4. Total dry weight, leaf area, total plant $\mathrm{N}$ content, and shoot:root ratio of Euonymus alatus 'Compactus' grown in 3.8-L containers with controlled-release, constant $\mathrm{N}$ rate, and sliding-scale liquid fertilizer treatments (2002).

\begin{tabular}{|c|c|c|c|c|}
\hline Treatment $^{\mathrm{z}}$ & $\begin{array}{c}\text { Total dry } \\
\text { wt (g) }\end{array}$ & $\begin{array}{l}\text { Leaf area } \\
\left(\mathrm{cm}^{2}\right)\end{array}$ & $\begin{array}{c}\text { Total plant } \mathrm{N} \\
(\mathrm{mg})\end{array}$ & $\begin{array}{l}\text { Shoot to } \\
\text { root ratio }\end{array}$ \\
\hline$\overline{\mathrm{INC}-\mathrm{HI}}$ & $5.6 \mathrm{~b}^{\mathrm{y}}$ & $141.2 \mathrm{~b}$ & $137.1 \mathrm{~b}$ & $2.6 \mathrm{c}$ \\
\hline TOP-HI & $11.1 \mathrm{a}$ & $273.6 \mathrm{a}$ & $239.5 \mathrm{a}$ & $3.7 \mathrm{abc}$ \\
\hline TOP-HI(30) & $8.2 \mathrm{ab}$ & $182.9 \mathrm{ab}$ & $166.1 \mathrm{ab}$ & $3.1 \mathrm{bc}$ \\
\hline INC-MED & $9.4 \mathrm{ab}$ & $261.1 \mathrm{ab}$ & $217.7 \mathrm{ab}$ & $3.7 \mathrm{abc}$ \\
\hline TOP-MED & $7.0 \mathrm{ab}$ & $181.3 \mathrm{ab}$ & $156.1 \mathrm{ab}$ & $3.1 \mathrm{bc}$ \\
\hline CONST & $5.4 \mathrm{~b}$ & $147.7 \mathrm{~b}$ & $143.3 \mathrm{~b}$ & $4.8 \mathrm{a}$ \\
\hline EU-DLY & $8.1 \mathrm{ab}$ & $250.5 \mathrm{ab}$ & $150.9 \mathrm{~b}$ & $4.5 \mathrm{ab}$ \\
\hline EU-BIWK & $8.8 \mathrm{ab}$ & $242.4 \mathrm{ab}$ & $202.4 \mathrm{ab}$ & $4.4 \mathrm{ab}$ \\
\hline
\end{tabular}

${ }^{2} \mathrm{INC}-\mathrm{HI}=$ incorporate at the high rate $\left(7.12 \mathrm{~kg} \cdot \mathrm{m}^{-3}\right), \mathrm{TOP}-\mathrm{HI}=$ top-dress at the high rate $(18 \mathrm{~g} / \mathrm{container})$, TOP-HI(30) = top-dress at the high rate $30 \mathrm{~d}$ after planting, INC-MED $=$ incorporate at the medium rate $\left(5.34 \mathrm{~kg} \cdot \mathrm{m}^{-3}\right)$, TOP-MED $=$ topdress at the medium rate $(14 \mathrm{~g} /$ container $)$, CONST $=200 \mathrm{mg} \cdot \mathrm{L}^{-1} \mathrm{~N} \mathrm{de}-$ livered Mon., Wed. and Fri., EU-DLY = daily sliding-scale treatments to Euonymus alatus 'Compactus', EU-BIWK = biweekly sliding-scale treatments to Euonymus alatus 'Compactus'.

${ }^{y}$ Means within columns followed by the same letter are not significantly different $(\alpha=0.05)$ by Duncan's multiple range test.

liquid treatments (EU-DLY and EU-BIWK) were similar to plants grown with the CRF treatments, but the shoot to root ratio of plants grown with the sliding-scale liquid treatments was higher than that of the CRF treatments.

Nitrogen uptake efficiency (total plant N/ total $\mathrm{N}$ applied) was calculated for WG-DLY, WG-BIWK, EU-DLY, EU-BIWK, and CONST, and comparisons were made within each taxon (Table 5). For both taxa, the slidingscale liquid $\mathrm{N}$ treatments resulted in higher $\mathrm{N}$ uptake efficiency than the CONST treatment. Nitrogen uptake efficiency, though dependent on many factors, is a function of the amount of $\mathrm{N}$ applied. If total plant $\mathrm{N}$ remains constant while the amount of $\mathrm{N}$ applied decreases, $\mathrm{N}$ uptake efficiency will increase. In this experiment, less $\mathrm{N}$ was applied with the sliding-scale liquid treatments (1837.5 and $1015 \mathrm{mg}$ for Weigela and Euonymus, respectively) than with the CONST treatment (2900 mg; Table 1), but total plant $\mathrm{N}$ was similar across all liquid $\mathrm{N}$ treatments (Table 3 and 4). Therefore, higher $\mathrm{N}$ uptake efficiency values were realized with the sliding-scale liquid treatments than with the CONST treatment. Comparisons of $\mathrm{N}$

Table 5. Nitrogen uptake efficiency of Weigela florida 'Red Prince' and Euonymus alatus 'Compactus' grown in 3.8-L containers with constant $\mathrm{N}$ rate and sliding-scale liquid fertilizer treatments (2002).

\begin{tabular}{|c|c|}
\hline Treatment $^{2}$ & $\begin{array}{c}\mathrm{N} \text { uptake efficiency } \\
\text { (total plant } \mathrm{N} / \text { total } \mathrm{N} \text { applied) }\end{array}$ \\
\hline \multicolumn{2}{|c|}{ Weigela florida 'Red Prince’' } \\
\hline WG-DLY & $42.7 \mathrm{a}^{\mathrm{y}}$ \\
\hline WG-BIWK & $43.7 \mathrm{a}$ \\
\hline CONST & $31.5 \mathrm{~b}$ \\
\hline \multicolumn{2}{|c|}{ Euonymus alatus 'Compactus' } \\
\hline EU-DLY & $14.9 \mathrm{a}$ \\
\hline EU-BIWK & $19.9 \mathrm{a}$ \\
\hline CONST & $4.9 \mathrm{~b}$ \\
\hline
\end{tabular}

${ }^{2} \mathrm{WG}-\mathrm{DLY}=$ daily sliding-scale treatments to Weigela florida 'Red Prince', WG-BIWK = biweekly sliding-scale treatments to Weigelaflorida 'Red Prince', CONST $=200 \mathrm{mg} \cdot \mathrm{L}^{-1} \mathrm{~N}$ delivered Mon., Wed. and Fri. to both taxa, EU-DLY = daily sliding-scale treatments to Euonymus alatus 'Compactus', EU-BIWK = biweekly sliding-scale treatments to Euonymus alatus 'Compactus',

${ }^{y}$ Means within a taxon and column followed by the same letter are not significantly different $(\alpha=0.05)$ by Duncan's multiple range test. uptake efficiency did not include CRF treatments because the amount of $\mathrm{N}$ released and retained in the prills at the time of harvest was not determined. However, several studies have suggested that the effective $\mathrm{N}$ release of Osmocote $18 \mathrm{~N}-2.6 \mathrm{P}-9.9 \mathrm{~K}$ under nursery conditions is about 120 to $150 \mathrm{~d}$ depending on temperature and moisture levels during the season (Huett and Gojel, 2000; Meadows and Fuller, 1983). Considering air temperature, rainfall data (Fig. 3), and irrigation volumes (Table 1), if all of the $\mathrm{N}$ was released from the tures (A) and rainfall (B) at the experimental site (Lewis Brown Horticulture Farm, Corvallis, Ore.) from planting (1 Apr. 2002) to harvest (20 Aug. 2002)
Fig. 3. Daily maximum and minimum air tempera-
CRF treatments during the 142-d experimental period, higher $\mathrm{N}$ uptake efficiencies may have been realized with the sliding-scale liquid $\mathrm{N}$ treatments because they introduced less $\mathrm{N}$ to each container.

Shoot to root ratios of both taxa were higher with liquid fertilization than with CRF treatments (Table 3 and 4). The highest shoot to root ratios occurred with the CONST treatment. Previous studies have reported increased shoot to root ratios with increased $\mathrm{N}$ amounts for several woody landscape plants (Cabrera, 2003; Cabrera and Devereaux, 1998; Henry et al., 1992; Hummel et al., 1990; Yeager and Wright, 1981). This response is attributed to plants' inherent tendency toward homeostasis by compensating for carbon or $\mathrm{N}$ imbalances (Cabrera and Devereaux, 1998). Under ample $\mathrm{N}$ supply, carbon may become the limiting factor to plant growth. Plants respond by allocating resources to shoots and leaves for the acquisition of carbon (Cabrera and Devereaux, 1998). Container-grown plants with high shoot to root ratios may be predisposed to slow establishment and greater mortality rates when planted into a landscape environment that is less intensively managed (Cabrera and Devereaux, 1998).

The WG-DLY and WG-BIWK treatments delivered the same total amount of $\mathrm{N}$ with 104 and $30 \mathrm{~N}$ applications, respectively (Table 2). The WG-DLY treatment supplied solutions with relatively low $\mathrm{N}$ concentrations daily, and the WG-BIWK treatment supplied solutions with higher $\mathrm{N}$ concentrations but less frequently (biweekly). Total plant dry weight, leaf area, total plant $\mathrm{N}$, and shoot to root ratios were similar for Weigela regardless of whether

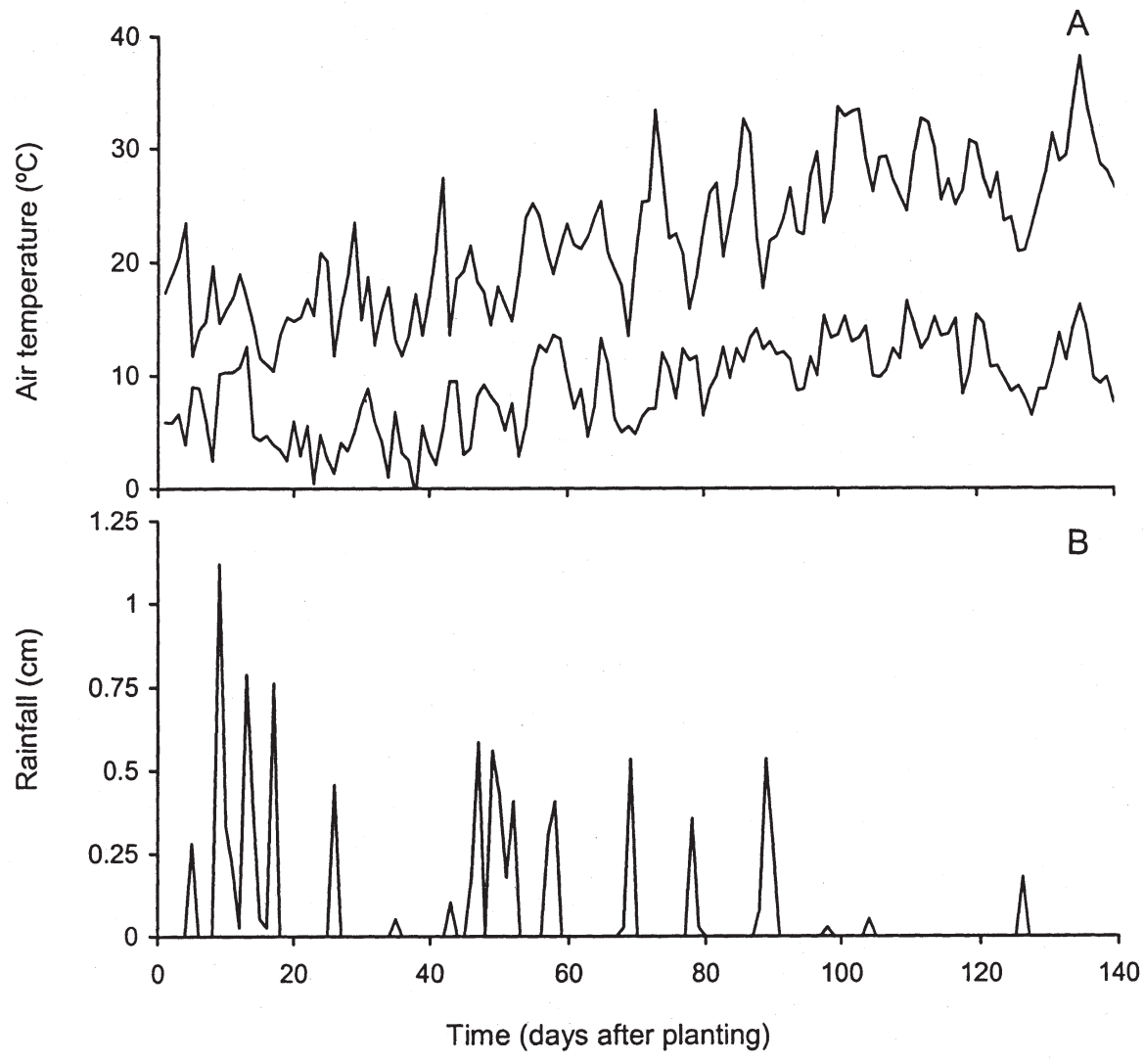


the applied $\mathrm{N}$ was delivered daily (WG-DLY) or biweekly (WG-BIWK). The EU-DLY and EU-BIWK treatments were delivered with 90 and $26 \mathrm{~N}$ applications, respectively (Table 2). Like Weigela, total plant dry weight, leaf area, total plant $\mathrm{N}$, and shoot to root ratios for Euonymus plants were similar regardless of daily or biweekly supply. According to this data, biweekly applications are adequate for the growth of Weigela and Euonymus. Greater precision, accomplished by more frequent applications at lower $\mathrm{N}$ concentrations, may not be necessary. A fertilizer program designed with fewer applications requires less solution preparation and allows for more flexible scheduling of applications to multiple crops.

At 93 dafter planting, the $\mathrm{pH}$ of the substrate for all treatments ranged from 6.1 to 6.6 , and the electrical conductivity (EC) ranged from 0.19 to $0.84 \mathrm{dS} \cdot \mathrm{m}^{-1}$. In Euonymus, liquid treatments yielded lower pHs and higher ECs in the substrate than the CRF treatments (data not shown). However, all values were within the recommended range for container-grown woody nursery crops (Wright, 1984; Yeager et al., 1997).

To implement a sliding-scale liquid fertilization program on a commercial scale, researchers and commercial nurseries will have to determine seasonal $\mathrm{N}$ accumulation patterns for each taxon produced. Existing drip irrigation and fertigation technology (Daughtry, 1990; Qcom, 2003; Whiteside, 1989) will have to be employed to avoid water and nutrient losses associated with overhead irrigation (Beeson and Knox, 1991). In addition, plants should be organized into groups with similar $\mathrm{N}$ requirements so that single applications can be made to large groups. Such a fertilization regime may be best suited for high value crops grown in large containers. As an example of a nursery that has reorganized production, El Modeno Gardens, a 95-acre container nursery in California, divided their plants into 64 groups according to water needs and used trickle irrigation to replenish specific crop evapotranspiration (Whiteside, 1989).

Sliding-scale liquid N fertilizer treatments resulted in plants with similar total dry weights, leaf areas, and total plant $\mathrm{N}$ contents, but higher shoot to root ratios than plants treated with Osmocote $18 \mathrm{~N}-2.6 \mathrm{P}-9.9 \mathrm{~K}$. Sliding-scale liquid fertilization based on plant $\mathrm{N}$ requirements introduced less total $\mathrm{N}$ to the production cycle and resulted in higher $\mathrm{N}$ uptake efficiency than fertilization with a constant $\mathrm{N}$ rate of 200 $\mathrm{mg} \cdot \mathrm{L}^{-1}$. Finally, a sliding-scale fertilization program based on biweekly $\mathrm{N}$ delivery is an appropriate level of precision when matching $\mathrm{N}$ applications to established $\mathrm{N}$ accumulation patterns of Weigela and Euonymus.

\section{Literature Cited}

Argo, W.R. and J.A. Biernbaum. 1991. The effect of fertilizer, nutrient charge, and irrigation method on early vegetative growth of poinsettia 'V-14 Glory'. HortScience 26:763 (abstr.).

Barnett, C.E. and D.P. Ormrod. 1985. Responses of Tilia cordata and Acer platanoides in pots to nitrogen levels. HortScience 20:283-285.

Beeson, Jr., R.C.and G.W. Knox. 1991. Analysis of efficiency of overhead irrigation in container production. HortScience 26:848-850.

Bunt, A.C. 1988. Substrate and mixes for containergrown plants. Unwin Hyman, London.

Cabrera, R.I. 1997. Comparative evaluation of nitrogen release patterns from controlled release fertilizers by nitrogen leaching analysis. HortScience 32:669-673.

Cabrera, R.I. 2003. Nitrogen balance for two container-grown woody ornamental plants. Scientia Hort. 97:297-308.

Cabrera, R.I. and D.R. Devereaux. 1998. Effects of nitrogen supply on growth and nutrient status of containerized crape myrtle. J. Environ. Hort. 16:98-104.

Cabrera, R.I., R.Y. Evans, and J.L. Paul. 1993. Leaching losses of $\mathrm{N}$ from container-grown roses. Scientia Hort. 53:333-345.

Craig, J.L., B.A. Birrenkott, and D.K. Struve. 2003. Nutrient uptake and dry weight patterns of three container-grown woody species. J. Environ. Hort. 21(4):209-215.

Daughtry, B. 1990. Conservation of water and fertilizer using pulse irrigation. Proc. Intl. Plant Prop. Soc. 40:390-393.

Dubois, J.B., S.L. Warren, and F.A. Blazich. 2000. Nitrogen nutrition of containerized Anemone $\times$ hybrida. J. Environ. Hort. 18:145-148.

Fain, G.B., C.H. Gilliam, K.M. Tilt, J.W. Olive, and B. Wallace. 2000. Survey of best management practices in container production nurseries. J. Environ. Hort. 18:142-144.

Griffin, J.J., S.L. Warren, F.A. Blazich, and T.G. Ranney. 1999. Nitrogen nutrition of containerized Thuja × 'Green Giant'. J. Environ. Hort. 17:76-79.

Hanson, E.J. and G.S. Howell. 1995. Nitrogen accumulation and fertilizer use efficiency by grapevines in short-season growing areas. HortScience 30:504-507.

Henry, P.H., F.A. Blazich, L. Hinesley, and R.D. Wright. 1992. Nitrogen nutrition of containerized Eastern redcedar. I. Growth, mineral nutrient concentrations, and carbohydrate status. J.Amer. Soc. Hort. Sci. 117:563-567.

Hershey, D.R. and J.L. Paul. 1982. Leaching losses from pot chrysanthemums with controlledrelease or liquid fertilization. Scientia Hort. 13:173-179.

Hicklenton, P.R. and K.G. Cairns. 1992. Solubility and application rate of controlled-release fertilizer affect growth and nutrient uptake in containerized woody landscape plants. J. Amer. Soc. Hort. Sci. 117:578-583.

Hilen, A.G. and G.L. Good. 1985. Predicting dry matter, $\mathrm{N}, \mathrm{P}$, and $\mathrm{K}$ accumulation in fieldgrown early Forsythia. J. Amer. Soc. Hort. Sci. 110:503-506.

Horneck, D.A., J.M. Hart, K. Topper, and B. Kopsell. 1989. Methods of soil analysis used in the soil testing laboratory at Oregon State University. Ore. State Univ. Agr. Expt. Sta., Corvallis.

Huett, D.O. 1997. Fertiliser use efficiency by containerized nursery plants. I. Plant growth and nutrient uptake. Austral. J. Agr. Res. 48:251-258.

Huett, D.O. and B.J. Gojel. 2000. Longevities and nitrogen, phosphorus, and potassium release patterns of polymer-coated controlled-release fertilizers at $30{ }^{\circ} \mathrm{C}$ and $40{ }^{\circ} \mathrm{C}$. Commun. Soil Sci. Plant Anal. 31:959-973.

Hummel, R.L., C.R. Johnson, and O.M. Lindstrom. 1990. Root and shoot growth response of three container-grown Kalmia latifolia L. cultivars at two locations to growing medium and nitrogen forms. J. Environ. Hort. 8:10-13.

Ingestad, T. 1982. Relative addition rate and external concentration; driving variables used in plant nutrition research. Plant Cell Environ. 5:443-453.
Johnson, C.R., J.T. Midcap, and D.F. Hamilton. 1981 Evaluation of potting media, fertilizer source and rate of application on chemical composition and growth of Ligustrum japonicum Thunb. Scientia Hort. 14:157-163.

Jull, L.G., S.L. Warren, F.A. Blazich. 1994. Nitrogen nutrition of containerized Cryptomeria japonica 'Elegans Aurea'. J. Environ. Hort. 12:212-215.

King, J. and D. Stimart. 1990. Quantities and forms of N uptake throughout development in chrysanthemum. HortScience 25:1170 (abstr.).

Marschner, H. 1995. Mineral nutrition of higher plants. 2nd ed. Academic Press, San Diego, Calif.

Maynard, D.N. and O.A. Lorenz. 1980. Controlledrelease fertilizers for horticultural crops. Hort. Rev. 1:79-140.

Meadows, W.J. and D.L. Fuller. 1983. Nitrogen and potassium release patterns of five formulations of Osmocote fertilizers and two micronutrient mixes for container-grown woody ornamentals. S. Nurserymen Assn. Res. J. 9:28-34.

Mengel, K. and E.A. Kirkby. 1987. Principles of plant nutrition. 4th ed. Intl. Potash Inst., Bern, Switzerland.

Munoz, M., J. Guerri, and E. Primo-Millo. 1993. Seasonal uptake of $15 \mathrm{~N}$-nitrate and distribution of absorbed nitrogen in peach trees. Plant and Soil 150:263-269.

Niemiera, A.X. and R.D. Wright. 1982. Growth of Ilexcrenata Thunb. 'Helleri' at different substrate nitrogen levels. HortScience 17:354-355.

Qcom Corportion. 2003. The Fertigator. 15 Mar. 2004. http://www.qcomcorp.com/products/fertigator.php.

Rose, M.A. and B. Biernacka. 1999. Seasonal patterns of nutrient and dry weight accumulation in freeman maple. HortScience 34:91-95.

Rose, M.A., J.W. White, and M.A. Rose. 1994. Maximizing nitrogen-use efficiency in relation to the growth and development of poinsettia. HortScience 29:272-276.

van der Boon, J. and H. Niers. 1983. Leaching of nutrients from containers with nursery plants. Acta Hort. 150:227-235.

Whitcomb, C.E. 1986. Landscape plant production, establishment, and maintenance. Lacebark Inc., Stillwater, Okla.

Whiteside, R. 1989. El Modeno Gardens: Innovative solutions to California's irrigation runoff restrictions. Grower Talks 59(2):28-36.

Wienbaum, S.A., M.L. Merwin, and T.T. Muraoka. 1978. Seasonal variation in nitrate uptake efficiency and distribution of absorbed nitrogen in non-bearing prune trees. J. Amer. Soc. Hort. Sci. 103:516-519.

Wright, R.D. 1984. The pour-through nutrient extraction procedure. Hortscience 21:227-229.

Wright, R.D. and A.X. Niemiera. 1987. Nutrition of container-grown woody nursery crops. Hort. Rev. 9:75-101.

Yeager, T.H. and G. Cashion. 1993. Controlled release fertilizer affects nitrate nitrogen runoff from container plants. HortTechnology 3:174-177.

Yeager, T.H. and R.D. Wright. 1981. Influence of nitrogen and phosphorus on shoot:root ratio of Ilex crenata Thunb. 'Helleri'. HortScience $16: 564-565$

Yeager, T.H., C.H. Gilliam, T.E. Bilderback, D.C. Fare, A.X. Niemiera, and K.M. Tilt. 1997. Best management practices guide for producing container-grown plants. S. Nurserymen Assn. Marietta, Ga.

Yeager, T.H., W.J. Foster, and W.R. Summerhill Jr. 1986. Fertilization characteristics of wholesale woody ornamental container nurseries in Florida. Univ. Fla. Coop. Ext. Serv. Circ. 696. 